\title{
Yara Yeri Örneklerinden İzole Edilen Etkenler ve Antibiyotik Direnç Profilleri
}

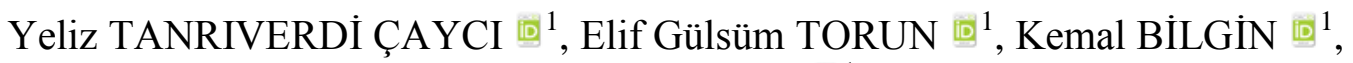 \\ Asuman BİRINCI ing $^{1}$
}

ÖZ

Amaç: Çeşitli yara tiplerinde oluşabilecek enfeksiyonlar günümüzde tıbbi açıdan önemini korumaya devam etmektedir. Çalışmamızda, 2015-2017 yılları arasında Ondokuz Mayıs Üniversitesi Tıp Fakültesi Tıbbi Mikrobiyoloji Laboratuvarı'na gönderilen yara yeri örneklerinden izole edilen mikroorganizmaların retrospektif olarak değerlendirilmesi ve antibiyotik direnç profillerinin saptanması amaçlanmıştır.

Gereç ve Yöntemler: Laboratuvarımıza farklı kliniklerden gönderilen yara yeri örneklerinin klasik yöntemlerle kültürü yapılmıştır. Üreme gözlenen kültürlerden izole edilen suşların tanımlanmasında Vitek MS (BioMérieux, Fransa) ve antibiyotik direnç durumlarının belirlenmesinde VITEK 2 (BioMerieux, Fransa) otomatize sistemi kullanılmıştır.

Bulgular: Toplam 3820 izolatın 2487'sini $(\% 65,1)$ Gram negatif bakteriler, 1281 'ini $(\% 33,5)$ Gram pozitif bakteriler ve 52 'sini $(\% 1,4)$ mantarlar oluşturmaktadır. Yara enfeksiyonu etkenlerinin en sık izole edildiği klinik genel cerrahi $(\% 20,8)$ olarak saptanmıştır. İzole edilen bakteriler içinde ilk sırada Escherichia coli yer alırken takibinde metisilin duyarlı Staphylococcus aureus (MSSA) ve Pseudomonas aeruginosa tespit edilmiștir. Enterobacteriacea türlerinin en duyarlı olduğu antibiyotikler amikasin, imipenem ve meropenem olarak bulunmuştur. P. aeruginosa ve Acinetobacter baumannii izolatlarının en duyarlı olduğu antibiyotik kolistin olarak bulunmuştur. S. aureus suşlarının 145 'i $(\% 23,1)$ ve koagülaz negatif stafilokokların 82 'si $(\% 58,9)$ metisiline dirençli bulunmuştur. Glikopeptitlere karşı direnç tespit edilmemiştir.

Sonuç: Günümüzde yara enfeksiyonları önemli bir sağlık sorunu olmaya devam etmektedir. Bu enfeksiyonlar farklı mikroorganizmalar tarafından oluşturulabilmektedir. Ayrıca antibiyotiklere dirençli mikroorganizmalarda etken olarak karşımıza çıkabilmekte ve tedavide güçlükler yaşanabilmektedir. Yara enfeksiyonu etkeni olan mikroorganizmalar ve bunların antibiyotik duyarlılıklarının belirli zaman aralıklarında takip edilmesinin tedaviye ışık tutması açısından önemli olacağı düşünülmektedir.

Anahtar Kelimeler: Antibiyotik direnci; mikroorganizmalar; yara kültürü.

\section{Microorganisms Isolated From Wound Specimens and Antibiotic Resistance Profiles}

\begin{abstract}
Aim: Infections that may occur in various wound types continue to preserve their medical importance. In this retrospective study it was aimed to evaluate the distribution and antibiotic susceptibility of the microorganisms isolated from wound samples in Ondokuz Mayıs University Faculty of Medicine Medical Microbiology Laboratory between years 2015-2017.

Material and Methods: Wound samples were evaluated by routine culture methods and identification were done by Vitek MS automatedsystem (BioMérieux, France) and antibiotic susceptibility testing were done by VITEK 2 automated system (BioMerieux, France).

Results: A total of 3820 samples, 1281(33.5\%) being gram positive bacteria, $2487(65.1 \%)$ being gram negative bacteria and $52(1.4 \%)$ were fungi. The rate of wound infections was highest in the General Surgery (20.8\%) clinic. The most commonly isolated microorganisms were Escherichia coli, methicillin susceptible Staphylococcus aureus (MSSA) and Pseudomonas aeruginosa. The most susceptible of the Enterobacteriacea species are found as amikacin, imipenem and meropenem. Colistin was found to be most susceptible antibiotic for P. aeruginosa and Acinetobacter baumannii. Methicillin resistance was detected in 145 (\%23.1) of S. aureus strains and $82(58.9 \%)$ of coagulase negative
\end{abstract}

1 Ondokuz Mayıs Üniversitesi, Tıp Fakültesi, Tıbbi Mikrobiyoloji Anabilim Dalı, Samsun, Türkiye

Sorumlu Yazar / Corresponding Author: Yeliz TANRIVERDi ÇAYCI, e-mail: yeliztanriverdi@gmail.com Geliş Tarihi / Received: 09.05.2019, Kabul Tarihi / Accepted: 18.01.2021 
staphylococci, glycopeptides resistance were not detected among staphylococci.

Conclusion: Wound infections remain an important health problem today. These infections can be caused by different microorganisms. In addition, antibiotic resistant microorganisms can be seen as an agent and may have difficulties in treatment. The distribution and antibiotic susceptibility of the microorganisms in wound infections should be determined periodically in each institution to guide empirical antibiotic treatment.

Keywords: Antibiotic resistance; microorganisms; wound culture.

\section{GíRIS}

Enfeksiyon hastalıkları gelişmekte olan ülkelerde önemli bir sağlık sorunu olmaya devam etmektedir (1). Bunlar arasında yara yeri enfeksiyonları önemli bir yer tutmaktadır (2). En önemli etkenler gram pozitif koklar (özellikle S. aureus), beta hemolitik streptokoklar ve koagulaz negatif stafilokoklardır (KNS). Anaerop bakteriler daha nadir etkenler olmakla birlikte özellikle iskemi ve gangren olan yaralarda miksenfeksiyon şeklindedir (3).

Cilt bütünlüğünün bozulmasının ardından deri altı dokusunun sicak ve nemli ortama maruz kalması mikrobiyalkolonizasyon ve proliferasyon için besleyici ortam oluşturmaktadır. Yara kolonizasyonu çoğu zaman polimikrobiyal olduğundan, potansiyel patojen mikroorganizmaları içeren bir enfeksiyon riski altındadır (4).

Yara enfeksiyonu, ilişkili konak reaksiyonu ile dokudaki bakteri birikimini ve çoğalmasını ifade etmektedir (5). Yarada enfeksiyon varlığına, şişlik kızarıklık ısı artışı ve hassasiyet olması ve bu bulgulardaki ilerleyici artışın periyodik takibi ile klinik olarak karar verilir (6).

Yara yeri enfeksiyonları, hastane kaynaklı enfeksiyonların en yaygın olanlarından birisidir. Önemli bir morbidite ve mortalite sebebidir. Bu tür enfeksiyonlar geç iyileşmekte, hastada anksiyeteye ve hastanede kalış süresinin uzamasına neden olmakta, sağlık sistemine önemli ölçüde mali yük getirmektedir (7). Bu nedenle belli zaman aralıklarında sık görülen enfeksiyon etkenleri ve bunlara antibiyotik duyarlılıklarının belirlenmesi ampirik tedaviye ışık tutması açısından önemlidir (8).

$\mathrm{Bu}$ çalışmada Tıbbi Mikrobiyoloji Laboratuvarına gönderilen yara yeri örneklerinden izole edilen mikroorganizmaların dağılımları ve bunların çeşitli antibiyotiklere duyarlılıklarının değerlendirilmesi amaçlanmıştır.

\section{GEREÇ VE YÖNTEMLER}

Bu çalışmada, Ondokuz Mayıs Üniversitesi Tıp Fakültesi Tıbbi Mikrobiyoloji Laboratuvarı'na, 2015-2017 y1lları arasında çeşitli servis ve polikliniklerden gönderilen yara yeri örneklerinden izole edilen mikroorganizmalar ve antibiyotik duyarlılıkları retrospektif olarak değerlendirildi. Çalışmamız Ondokuz Mayıs Üniversitesi Klinik Araştırmalar Etik Kurulu'nun 27/09/2019 tarihinde verdiği B.30.2.ODM.0.20.08/726 sayılı izin ile yürütüldü.

Çalışmada 3820 örnek değerlendirmeye alındı. Örnekler steril şartlarda alınmış ve uygun koşullarda laboratuvarımıza ulaştırıldı.
Bakteriyel etken düşünülen örnekler $\% 5$ koyun kanlı agar (BioMérieux, Fransa), eozin metilen mavili (EMB) agar (BioMérieux, Fransa) besiyerlerine ekilerek $37^{\circ} \mathrm{C}$ 'de 18 24 saat inkübe edildi. Mantar etkenleri düşünülen etkenler Sabouraud Dekstroz Agar (Difco), Patates Dekstroz Agar (Acumedia) ve Mycobiotic Agar (Acumedia) besiyerine ekildi ve uygun sicaklıkta uygun süre inkübe edildi. Bakteri ve mantar türlerinin tanımlanmasında Vitek MS (BioMérieux, Fransa) ve antibiyotik duyarlılığının belirlenmesinde Vitek2 Compakt (BioMérieux, Fransa) otomatize sistemleri kullanıldı. İzolatların antibiyotik duyarlılıklarının değerlendirilmesinde EUCAST kriterleri kullanıldı (9).

Çalışmaya dahil edilen etkenlerin, izole edildiği hastaların yattıkları servis dağılımı, hangi mikroorganizma oldukları ve antibiyotik duyarlılıkları sayısal olarak belirlenmiş ve yüzde olarak hesaplanmıştır. Çalışmada araştırma ve yayın etiğine uyulmuştur.

\section{BULGULAR}

Laboratuvara gönderilen 3820 örnekten izole edilen mikroorganizmaların 1281'ini $(\% 33,5)$ gram pozitif bakteriler, 2487'sini $(\% 65,1)$ gram negatif bakteriler, 52'sini $(\% 1,4)$ mantarlar oluşturmaktadır (Tablo 1).

Tablo 1. İzole edilen mikroorganizmalar

\begin{tabular}{|l|c|}
\hline Mikroorganizmalar & Say1 $(\%)$ \\
\hline Gram negatif bakteriler & $2487(65,1)$ \\
\hline Gram pozitif bakteriler & $1281(33,5)$ \\
\hline Maya & $52(1,4)$ \\
\hline Toplam & 3820 \\
\hline
\end{tabular}

Etkenlerin 2911'i $(\% 76,2)$ yatan hastalara, 909'u $(\% 23,8)$ poliklinik hastalarına ait örneklerden izole edilmiştir. Yara enfeksiyonu etkenlerinin sıklıkla izole edildiği klinik genel cerrahi $(\% 20,8)$ olarak saptanmıştır. Bunu sirasıyla plastik ve rekonstriktif cerrahi $(\% 11,0)$ ve dermatoloji $(\% 8,3)$ bölümleri izlemiştir. İzole edilen bakteriler içinde en sık $E$. coli, daha sonrada diğer enterik bakteriler, MSSA ve $P$. aeruginosa olduğu tespit edilmiştir (Tablo 2).

Kliniklere göre izole edilen etken dağılımına bakıldığında genel cerrahi kliniğinden gelen yara örneklerinden çoğunlukla izole edilen etken E. coli $(\% 41,8)$ olurken; plastik ve rekonstriktif cerrahi kliniğinden diğer enterik bakteriler $(\% 27,0)$, dermatoloji kliniğinden ise MSSA sıklıkla $(\% 27,8)$ izole edilmiştir.

Enterobacteriacea türlerinin çeşitli antibiyotiklere direnç oranları Tablo 3'te gösterilmiştir. Buna göre duyarlılığın yüksek olduğu antibiyotikler amikasin, imipenem ve meropenem olarak bulunmuştur.

Yara örneklerinden izole edilen $P$. aeruginosa ve $A$. baumannii izolatlarının duyarlılığının yüksek olduğu antibiyotik kolistin olarak bulunmuştur (Tablo 4).

İzole edilen $S$. aureus suşlarının $145^{\prime}$ i $(\% 23,0)$ ve KNS 'lerin 82'si $(\% 58,9)$ metisiline dirençli bulunurken, glikopeptitlere karşı direnç tespit edilmemiştir. Stafilokok suşlarının diğer antibiyotiklere direnç durumları Tablo 5'te gösterilmiştir. 
Tablo 2. İzole edilen etkenlerin kliniklere göre dağılımı (n(\%))

\begin{tabular}{|c|c|c|c|c|c|c|c|c|c|c|c|c|}
\hline Etken & 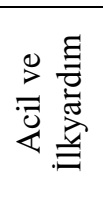 & $\begin{array}{l}:=\frac{1}{0} \\
\frac{0}{0} \\
\frac{\pi}{1} \\
\frac{0}{0} \\
0\end{array}$ & 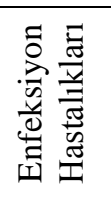 & 这 & 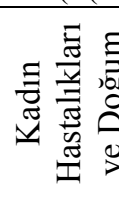 & $\begin{array}{l}:-\overline{0} \\
\frac{0}{0} \\
: \frac{0}{2}\end{array}$ & 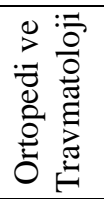 & 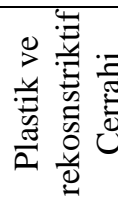 & $\frac{1}{0}$ & 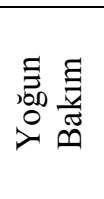 & 离 & $\frac{\Xi}{\frac{\Xi}{2}}$ \\
\hline E. coli & $\begin{array}{c}45 \\
(25,9) \\
\end{array}$ & $\begin{array}{c}21 \\
(6,6)\end{array}$ & $\begin{array}{c}23 \\
(9,8)\end{array}$ & $\begin{array}{c}333 \\
(41,8) \\
\end{array}$ & $\begin{array}{c}49 \\
(26,9) \\
\end{array}$ & $\begin{array}{c}8 \\
(8,0)\end{array}$ & $\begin{array}{c}11 \\
(7,1) \\
\end{array}$ & $\begin{array}{c}47 \\
(11,2)\end{array}$ & $\begin{array}{c}44 \\
(39,3) \\
\end{array}$ & $\begin{array}{c}38 \\
(18,8) \\
\end{array}$ & $\begin{array}{c}167 \\
(20,6) \\
\end{array}$ & $\begin{array}{c}786 \\
(20,5) \\
\end{array}$ \\
\hline K. pneumoniae & $\begin{array}{c}13 \\
(7,5)\end{array}$ & $\begin{array}{c}19 \\
(6,0)\end{array}$ & $\begin{array}{c}11 \\
(4,7)\end{array}$ & $\begin{array}{c}94 \\
(11,8)\end{array}$ & $\begin{array}{c}21 \\
(11,5)\end{array}$ & $\begin{array}{c}20 \\
(20,0)\end{array}$ & $\begin{array}{c}11 \\
(7,1)\end{array}$ & $\begin{array}{c}19 \\
(4,5)\end{array}$ & $\begin{array}{c}6 \\
(5,4)\end{array}$ & $\begin{array}{c}35 \\
(17,3)\end{array}$ & $\begin{array}{l}129 \\
(9,9)\end{array}$ & $\begin{array}{c}378 \\
(9,8)\end{array}$ \\
\hline $\begin{array}{l}\text { Diğer enterik } \\
\text { bakteriler }\end{array}$ & $\begin{array}{c}28 \\
(16,1)\end{array}$ & $\begin{array}{c}55 \\
(17,4)\end{array}$ & $\begin{array}{c}41 \\
(17,4)\end{array}$ & $\begin{array}{c}60 \\
(7,5)\end{array}$ & $\begin{array}{c}28 \\
(15,4)\end{array}$ & $\begin{array}{c}13 \\
(13,0)\end{array}$ & $\begin{array}{c}35 \\
(22,7)\end{array}$ & $\begin{array}{c}113 \\
(27,0)\end{array}$ & $\begin{array}{c}8 \\
(7,1)\end{array}$ & $\begin{array}{c}25 \\
(12,4)\end{array}$ & $\begin{array}{c}147 \\
(13,0)\end{array}$ & $\begin{array}{c}553 \\
(14,5)\end{array}$ \\
\hline P. aeruginosa & $\begin{array}{c}24 \\
(13,8) \\
\end{array}$ & $\begin{array}{c}37 \\
(11,7) \\
\end{array}$ & $\begin{array}{c}30 \\
(12,8) \\
\end{array}$ & $\begin{array}{c}56 \\
(7,0) \\
\end{array}$ & $\begin{array}{c}8 \\
(4,4) \\
\end{array}$ & $\begin{array}{c}20 \\
(20,0) \\
\end{array}$ & $\begin{array}{c}21 \\
(13,6) \\
\end{array}$ & $\begin{array}{c}78 \\
(18,6) \\
\end{array}$ & $\begin{array}{c}4 \\
(3,6) \\
\end{array}$ & $\begin{array}{c}18 \\
(8,9)\end{array}$ & $\begin{array}{c}149 \\
(13,2)\end{array}$ & $\begin{array}{c}445 \\
(11,6) \\
\end{array}$ \\
\hline A. baumannii & $\begin{array}{c}3 \\
(1,7) \\
\end{array}$ & $\begin{array}{c}9 \\
(2,8) \\
\end{array}$ & $\begin{array}{c}17 \\
(7,2)\end{array}$ & $\begin{array}{c}27 \\
(3,4)\end{array}$ & $\begin{array}{c}4 \\
(2,2) \\
\end{array}$ & $\begin{array}{c}14 \\
(14,0) \\
\end{array}$ & $\begin{array}{c}8 \\
(5,2) \\
\end{array}$ & $\begin{array}{c}18 \\
(4,3) \\
\end{array}$ & $\begin{array}{c}3 \\
(2,7) \\
\end{array}$ & $\begin{array}{c}32 \\
(15,8) \\
\end{array}$ & $\begin{array}{c}96 \\
(6,0)\end{array}$ & $\begin{array}{l}231 \\
(6,1) \\
\end{array}$ \\
\hline $\begin{array}{l}\text { Diğer } \\
\text { Nonfermentatif } \\
\text { bakteriler }\end{array}$ & $\begin{array}{c}3 \\
(1,7)\end{array}$ & $\begin{array}{c}12 \\
(3,8)\end{array}$ & $\begin{array}{c}8 \\
(3,4)\end{array}$ & $\begin{array}{c}3 \\
(0,4)\end{array}$ & $\begin{array}{c}1 \\
(0,6)\end{array}$ & $\begin{array}{c}1 \\
(1,0)\end{array}$ & $\begin{array}{c}4 \\
(2,6)\end{array}$ & $\begin{array}{c}22 \\
(5,3)\end{array}$ & $\begin{array}{c}4 \\
(3,6)\end{array}$ & 0 & $\begin{array}{c}26 \\
(2,3)\end{array}$ & $\begin{array}{c}84 \\
(2,2)\end{array}$ \\
\hline $\begin{array}{l}\text { Enterococcus } \\
\text { spp. }\end{array}$ & $\begin{array}{c}11 \\
(6,3)\end{array}$ & $\begin{array}{c}7 \\
(2,2)\end{array}$ & $\begin{array}{c}13 \\
(5,5)\end{array}$ & $\begin{array}{c}128 \\
(16,1)\end{array}$ & $\begin{array}{c}24 \\
(13,2)\end{array}$ & $\begin{array}{c}9 \\
(9,0)\end{array}$ & $\begin{array}{c}14 \\
(9,1)\end{array}$ & $\begin{array}{c}21 \\
(5,0)\end{array}$ & $\begin{array}{c}18 \\
(16,1)\end{array}$ & $\begin{array}{c}17 \\
(8,4)\end{array}$ & $\begin{array}{c}89 \\
(7,9)\end{array}$ & $\begin{array}{c}351 \\
(9,2)\end{array}$ \\
\hline MRSA & $\begin{array}{c}11 \\
(6,3)\end{array}$ & $\begin{array}{c}29 \\
(9,1)\end{array}$ & $\begin{array}{c}9 \\
(3,8) \\
\end{array}$ & $\begin{array}{c}10 \\
(1,3)\end{array}$ & $\begin{array}{c}10 \\
(5,5)\end{array}$ & $\begin{array}{c}5 \\
(5,0) \\
\end{array}$ & $\begin{array}{c}9 \\
(5,8) \\
\end{array}$ & $\begin{array}{c}14 \\
(3,3) \\
\end{array}$ & $\begin{array}{c}5 \\
(4,5) \\
\end{array}$ & $\begin{array}{c}1 \\
(0,5)\end{array}$ & $\begin{array}{c}42 \\
(3,7)\end{array}$ & $\begin{array}{c}145 \\
(3,8) \\
\end{array}$ \\
\hline MSSA & $\begin{array}{c}26 \\
(14,9) \\
\end{array}$ & $\begin{array}{c}88 \\
(27,8) \\
\end{array}$ & $\begin{array}{c}46 \\
(19,6) \\
\end{array}$ & $\begin{array}{c}35 \\
(4,4)\end{array}$ & $\begin{array}{c}19 \\
(10,4) \\
\end{array}$ & $\begin{array}{c}5 \\
(5,0) \\
\end{array}$ & $\begin{array}{c}25 \\
(16,2) \\
\end{array}$ & $\begin{array}{c}31 \\
(7,4) \\
\end{array}$ & $\begin{array}{c}9 \\
(8,0) \\
\end{array}$ & $\begin{array}{c}15 \\
(7,4)\end{array}$ & $\begin{array}{c}186 \\
(16,5)\end{array}$ & $\begin{array}{c}485 \\
(12,7) \\
\end{array}$ \\
\hline MRKNS & $\begin{array}{c}1 \\
(0,6)\end{array}$ & $\begin{array}{c}5 \\
(1,6)\end{array}$ & $\begin{array}{c}8 \\
(3,4)\end{array}$ & $\begin{array}{c}8 \\
(1,0)\end{array}$ & $\begin{array}{c}11 \\
(6,0)\end{array}$ & $\begin{array}{c}1 \\
(1,0)\end{array}$ & $\begin{array}{c}9 \\
(5,8)\end{array}$ & $\begin{array}{c}9 \\
(2,1)\end{array}$ & $\begin{array}{c}2 \\
(1,8)\end{array}$ & $\begin{array}{c}11 \\
(5,4)\end{array}$ & $\begin{array}{c}17 \\
(2,1)\end{array}$ & $\begin{array}{c}82 \\
(2,2)\end{array}$ \\
\hline MSKNS & $\begin{array}{c}3 \\
(1,7)\end{array}$ & $\begin{array}{c}14 \\
(4,4)\end{array}$ & $\begin{array}{c}3 \\
(1,3)\end{array}$ & $\begin{array}{c}9 \\
(1,1)\end{array}$ & $\begin{array}{c}2 \\
(1,1)\end{array}$ & 0 & $\begin{array}{c}2 \\
(1,3)\end{array}$ & $\begin{array}{c}9 \\
(2,1)\end{array}$ & $\begin{array}{c}1 \\
(0,9)\end{array}$ & $\begin{array}{c}2 \\
(1,0)\end{array}$ & $\begin{array}{c}12 \\
(1,1)\end{array}$ & $\begin{array}{c}57 \\
(1,5) \\
\end{array}$ \\
\hline $\begin{array}{l}\text { Diğer Gram } \\
\text { negatif bakteriler }\end{array}$ & 0 & $\begin{array}{c}2 \\
(0,6)\end{array}$ & $\begin{array}{c}1 \\
(0,4) \\
\end{array}$ & $\begin{array}{c}1 \\
(0,1) \\
\end{array}$ & 0 & 0 & $\begin{array}{c}1 \\
(0,6) \\
\end{array}$ & $\begin{array}{c}4 \\
(1,0) \\
\end{array}$ & 0 & 0 & $\begin{array}{c}1 \\
(0,1)\end{array}$ & $\begin{array}{c}10 \\
(0,3) \\
\end{array}$ \\
\hline $\begin{array}{l}\text { Diğer Gram } \\
\text { pozitif bakteriler }\end{array}$ & $\begin{array}{c}5 \\
(2,9)\end{array}$ & $\begin{array}{c}18 \\
(5,7)\end{array}$ & $\begin{array}{c}21 \\
(8,9)\end{array}$ & $\begin{array}{c}22 \\
(2,8)\end{array}$ & $\begin{array}{c}1 \\
(0,6)\end{array}$ & $\begin{array}{c}2 \\
(2,0) \\
\end{array}$ & $\begin{array}{c}3 \\
(1,9)\end{array}$ & $\begin{array}{c}33 \\
(7,9)\end{array}$ & $\begin{array}{c}5 \\
(4,5) \\
\end{array}$ & $\begin{array}{c}2 \\
(1,0)\end{array}$ & $\begin{array}{c}49 \\
(4,3)\end{array}$ & $\begin{array}{c}161 \\
(4,2)\end{array}$ \\
\hline Mantar & $\begin{array}{c}1 \\
(0,6)\end{array}$ & $\begin{array}{c}1 \\
(0,3) \\
\end{array}$ & $\begin{array}{c}4 \\
(1,7)\end{array}$ & $\begin{array}{c}10 \\
(1,3)\end{array}$ & $\begin{array}{c}4 \\
(2,2) \\
\end{array}$ & $\begin{array}{c}2 \\
(2,0) \\
\end{array}$ & $\begin{array}{c}1 \\
(0,6)\end{array}$ & $\begin{array}{c}1 \\
(0,5)\end{array}$ & $\begin{array}{c}3 \\
(2,7) \\
\end{array}$ & $\begin{array}{c}6 \\
(3,0) \\
\end{array}$ & $\begin{array}{c}19 \\
(1,7)\end{array}$ & $\begin{array}{c}52 \\
(1,4) \\
\end{array}$ \\
\hline Toplam & $\begin{array}{c}174 \\
(4,6)\end{array}$ & $\begin{array}{c}317 \\
(8,3)\end{array}$ & $\begin{array}{c}235 \\
(6,2)\end{array}$ & $\begin{array}{c}796 \\
(20,8)\end{array}$ & $\begin{array}{c}182 \\
(4,8)\end{array}$ & $\begin{array}{l}100 \\
(2,6)\end{array}$ & $\begin{array}{c}154 \\
(4,0)\end{array}$ & $\begin{array}{c}419 \\
(11,0)\end{array}$ & $\begin{array}{c}112 \\
(2,9)\end{array}$ & $\begin{array}{c}202 \\
(5,3)\end{array}$ & $\begin{array}{c}1129 \\
(29,6)\end{array}$ & $\begin{array}{l}3820 \\
(100)\end{array}$ \\
\hline
\end{tabular}

MRSA: Metisilin dirençli S. aureus, MSSA: Metisilin duyarlı S. aureus, MRKNS: Metisilin dirençli Koagülaz negatif stafilokok, MSKNS: Metisilin duyarlı koagülaz negatif stafilokok

Tablo 3. Enterobactericaea izolatlarında antibiyotiklere direnç oranları

\begin{tabular}{|l|c|c|c|}
\hline Antibiyotik & $\begin{array}{c}\text { E. coli } \\
\mathrm{n}(\%)\end{array}$ & $\begin{array}{c}\text { K. pneumoniae } \\
\mathrm{n}(\%)\end{array}$ & $\begin{array}{c}\text { Diğer enterik bakteriler } \\
\text { n }(\%)\end{array}$ \\
\hline Ampisilin & $657(83,6)$ & $378(100,0)$ & $493(89,2)$ \\
\hline Amoksisilin/klavulanat (diğer) & $200(25,4)$ & $112(29,6)$ & $172(31,1)$ \\
\hline Piperasilin/Tazobaktam & $247(31,4)$ & $205(54,2)$ & $72(13,0)$ \\
\hline Sefepim & $276(35,1)$ & $214(56,6)$ & $54(9,8)$ \\
\hline Seftazidim & $343(43,6)$ & $236(62,4)$ & $124(22,4)$ \\
\hline Seftriakson & $424(53,9)$ & $245(64,8)$ & $139(25,1)$ \\
\hline Sefuroksim & $476(60,6)$ & $263(69,6)$ & $308(55,7)$ \\
\hline Sefuroksimaksetil & $445(56,6)$ & $241(63,8)$ & $337(60,9)$ \\
\hline Ertapenem & $39(4,9)$ & $156(41,3)$ & $33(6,0)$ \\
\hline İmipenem & $6(0,8)$ & $89(23,5)$ & $17(3,1)$ \\
\hline Meropenem & $5(0,6)$ & $103(27,2)$ & $11(2,0)$ \\
\hline Siprofloksasin & $347(44,1)$ & $180(47,6)$ & $72(13,0)$ \\
\hline Amikasin & $11(1,4)$ & $26(6,9)$ & $5(0,9)$ \\
\hline Gentamisin & $156(19,8)$ & $103(27,2)$ & $66(11,9)$ \\
\hline Trimetoprim/Sülfametoksazol & $398(50,6)$ & $185(48,9)$ & $112(20,3)$ \\
\hline
\end{tabular}


Tablo 4. $P$. aeruginosa ve A. baumannii izolatlarında antibiyotiklere direnç oranları

\begin{tabular}{|l|c|c|}
\hline Antibiyotik & $\begin{array}{c}\text { P. aeruginosa } \\
\mathrm{n}=445(\%)\end{array}$ & $\begin{array}{c}\text { A. baumannii } \\
\mathrm{n}=231(\%)\end{array}$ \\
\hline Piperasilin & $114(25,6)$ & - \\
\hline Piperasilin/Tazobaktam & $90(20,2)$ & - \\
\hline Sefepim & $59(13,3)$ & - \\
\hline Seftazidim & $59(13,3)$ & $201(87,0)$ \\
\hline İmipenem & $79(17,8)$ & $201(87,0)$ \\
\hline Meropenem & $41(9,2)$ & $199(86,7)$ \\
\hline Siprofloksasin & $71(16,0)$ & $105(45,5)$ \\
\hline Levofloksasin & $92(20,7)$ & $150(64,9)$ \\
\hline Amikasin & $11(2,5)$ & $0(0,0)$ \\
\hline Gentamisin & $26(5,8)$ & $151(65,4)$ \\
\hline Kolistin & $0(0,0)$ & - \\
\hline Trimetoprim/Sülfametoksazol & - & \\
\hline
\end{tabular}

Tablo 5. Stafilokoklarda antibiyotiklere direnç oranları

\begin{tabular}{|l|c|c|c|c|}
\hline Antibiyotik & $\begin{array}{c}\text { MRSA } \\
\mathrm{n}=145(\%)\end{array}$ & $\begin{array}{c}\text { MSSA } \\
\mathrm{n}=485(\%)\end{array}$ & $\begin{array}{c}\text { MRKNS } \\
\mathrm{n}=82(\%)\end{array}$ & $\begin{array}{c}\text { MSKNS } \\
\mathrm{n}=57(\%)\end{array}$ \\
\hline Penisilin & $145(100,0)$ & $400(82,5)$ & $82(100,0)$ & $21(36,8)$ \\
\hline Eritromisin & $55(37,9)$ & $53(10,9)$ & $65(79,3)$ & $15(26,3)$ \\
\hline Klindamisin & $39(26,9)$ & $42(8,7)$ & $32(39,0)$ & $4(7,0)$ \\
\hline Trimetoprim/sülfametoksazol & $8(5,5)$ & $3(0,6)$ & $21(25,6)$ & $3(5,3)$ \\
\hline Siprofloksasin & $41(28,3)$ & $22(4,5)$ & $50(61,0)$ & $1(1,8)$ \\
\hline Gentamisin & $16(11,0)$ & $3(0,6)$ & $33(40,2)$ & $1(1,8)$ \\
\hline Tetrasiklin & $60(41,4)$ & $59(12,2)$ & $54(65,9)$ & $20(35,1)$ \\
\hline Vankomisin & 0 & 0 & 0 & 0 \\
\hline Teikoplanin & 0 & 0 & 0 & 0 \\
\hline Linezolid & $2(1,4)$ & 0 & 0 & 0 \\
\hline
\end{tabular}

MRSA: Metisilin dirençli S. aureus, MSSA: Metisilin duyarlı S. aureus, MRKNS: Metisilin dirençli koagülaz negatif stafilokok, MSKNS: Metisilin duyarlı koagülaz negatif stafilokok

\section{TARTIŞMA}

Enfeksiyona neden olan etkenlerin dağılımı ve antibiyotik duyarlılığı yıllar içerisinde değişiklik gösterebilmektedir. $\mathrm{Bu}$ nedenle sağlık kurumlarının kendi enfeksiyon etkenlerinin dağılımını ve antimikrobiyal ajanlara duyarlılık durumlarını gösteren düzenli sürveyans çalışmalarına ihtiyacı vardır (10). Yara yeri enfeksiyonları hastanın kendi florasında veya hastane ortamında bulunabilen bakterilerle meydana gelmektedir (11). $\mathrm{Bu}$ enfeksiyonlarının tedavisinde kültür ve antibiyogram değerlendirmesi tedavi başarısını arttırdığ 1 gibi toplam maliyeti düşürmede de oldukça etkili olduğu için enfekte bir yara karşısında mikrobiyoloji laboratuvarının sonuçları büyük önem taşımaktadır. Ayrıca antibiyotik kullanımının kontrolünü sağlama ve dirençli bakterilerin yayılımını engelleme bakımından da kültür ve duyarlılık sonuçları önem arz etmektedir $(2,12)$. $\mathrm{Bu}$ uygulama ile klinisyenin yara tedavisindeki başarısını etkileyecek antibiyotik kullanımının kontrolü ile dirençli bakterilerin yayılması da engellenmiş olacaktır (13).

Yurtsever ve ark. (2) yara yeri örneklerini değerlendirdikleri çalışmalarında en sık etken izole edilen kliniğin genel cerrahi olduğunu bulmuşlardır. Altan ve ark. (14) çalışmalarında yanık servisini, Sesli ve ark. (11) ve Cirit ve ark. (15) çalışmalarında ortopedi kliniğini en sık etken izole edilen klinik olarak belirlemişlerdir. Bizim çalışmamızda ise en sık örnek gönderilen klinik genel

cerrahi $(\% 20,8)$ olarak tespit edilmiştir.

Çalışmamızda yara yeri enfeksiyonlarından sıklıkla izole edilen etkenler sırasıyla $E$. coli $(\% 20,5)$, diğer enterik bakteriler $(\% 14,5)$, MSSA $(\% 12,7)$ ve $P$. aeruginosa $(\% 11,6)$ olmuştur. Sonuçlarımıza benzer şekilde Aşık ve ark. (16) genel cerrahi yoğun bakım ünitesinde yatan hastalarda yapmış oldukları çalışmada en sık izole edilen etkenleri E. coli $(\% 39,8), \quad S$. aureus $(\% 11,9), A$. baumannii $(\% 9,1)$ ve $P$. aeruginosa $(\% 7,5)$ olarak saptamışlardır. Doğan ve ark. (17) çalışmalarında yara yeri örneklerinden en sik izole edilen mikroorganizmanın E. coli $(\% 28,5)$ olduğunu ve bunu sirasiyla Enterobacter aerogenes $(\% 15,6), S$. aureus $(\% 14,8)$ ve $P$. aeruginosa (\%14) izolatlarının izlediğini bildirmişlerdir. Meksika'da yapılmış bir vaka kontrol çalışmasında 313 yara yeri enfeksiyonunda en sik izole edilen bakteriler sırasıyla; \%21,8 E. coli, \%13 KNS, \%12,6 Pseudomonas spp. ve $\% 9,2$ S. aureus olarak bildirilmiştir (18). Mama ve ark. (19) yaptıkları çalışmada, yara enfeksiyonu etkenlerini sirasiyla; \%32,4 S. aureus, \%20 E. coli, \%16 Proteus spp., \%14,5 KNS, \%10 K. pneumoniae ve \%8 $P$. aeruginosa olarak belirlemişlerdir. Gündem ve ark. (10) çalışmalarında yara yeri örneklerinden en sık izole edilen bakterilerin sirasıyla; \%32,4 ile S. aureus, \%25,3 ile KNS 
olduğunu ve bunları \%11,3 oranıyla $E$. coli’nin izlediğini bildirmişlerdir. Altan ve ark. (14) yapmış oldukları çalışmada ise en sik etkenler sirasıyla; \%28 $A$. baumannii, \%16,6 P. aeruginosa, \%11,4 Candida spp. ve $\% 9,3$ E. coli olarak bulunmuştur. Ülkemizde ve dünyada yapılan çalışmalarda, önceki yıllarda yara enfeksiyonlarında en sik rastlanan etkenler $S$. aureus suşları iken bunun yerini Gram negatif izolatların almaya başladığı görülmektedir. Bunun nedeninin son y1llarda tercih edilen ampirik tedavilere bağlı olarak hasta ve hastane florasının değişmesi olduğu düşünülmektedir. Ülkemizde yapılan birçok çalışmada (20-22) linezolid dirençli suş saptanmazken; yurt dişında yapılan bir çalışmada (23) linezolide dirençli $S$. aureus suşu bildirilmiştir. Yapılan birçok çalışmaya benzer şekilde çalışmamızda da stafílokok türlerinde vankomisin ve teikoplanine direnç gözlenmemiştir $(11,15,17)$.

Çalışmamıza dahil edilen $S$. aureus izolatlarında metisilin direnci \%23,0; KNS türlerinde ise \%58,9 olarak saptanmıştır. MRSA izolatları çoğunlukla dermatoloji kliniğinde; MRKNS türleri ise en sık kadın hastalıkları ve doğum kliniği ile yoğun bakım ünitelerinden izole edilmiştir. Ülkemizde yapılan diğer çalışmalarda metisilin direnci $S$. aureus ve KNS'lerde sırasıly Cirit ve ark. (15)'nın çalışmasında \%27,3 ve \%54,6; Özcan ve ark. (24)'nın çalışmasında \%38 ve \%53; Yurtsever ve ark. (2)'nın çalışmasında $\% 29$ ve $\% 50$; Polat ve ark. (25)'nın çalışmasında \%19,7 ve \% 7,6 olarak bulunmuştur. MRSA suşlarının ve KNS türlerinin hastane enfeksiyonlarında büyük rolü olduğu, metisilin direncinde bölgesel farklılıklar görülebildiği gibi aynı hastanenin farklı birimlerinde de farklı direnç oranları saptanabildiği bilinmektedir (10).

Çalışmamızda izole edilen Enterobactericaea üyelerinde genel olarak betalaktamlara yüksek direnç oranları saptanırken, imipenem, meropenem ve amikasin antibiyotik duyarlıklıkları yüksek oranda belirlenmiştir. Polat ve ark. (25) yaptıkları çalışmada Enterobactericaea'larda imipenem duyarlılığını \%97 olarak tespit edilirken, amikasin ve üçüncü kuşak sefalosporinlere duyarlılık sırasıyla \%57,2 ve \%56 olarak bulunmuştur. Doğan ve ark. (17) yapmış oldukları çalışmada Enterobactericaea'ların en duyarlı oldukları antibiyotikler imipenem, amikasin ve gentamisin olarak bulunmuştur.

Çalışmamızda izole edilen $P$. aeruginosa ve $A$. baumannii izolatlarında kolistin direnci saptanmamıştır.

A. baumannii izolatlarında yaygın çoklu antibiyotik direnci gözlenirken, $P$. aeruginosa izolatlarında en düşük direnç oranı amikasin $(\% 2,5)$, gentamisin $(\% 5,8)$ ve meropenemde $(\% 9,2)$ görülmüştür. Yapılan diğer çalışmalarla karşılaştırdığımızda A. baumannii için benzer sonuçlara ulaşılmıştır $(12,15)$. Aşık ve ark. (16) çalışmasında $P$. aeruginosa suşlarında amikasin dirençi $\% 77,5$, meropenem direnci $\% 70,6$ oranında saptanırken, Kiremitçi ve ark. (26) çalışmasında amikasin direnci $\% 42,8$, gentamisin direnci $\% 68,7$ ve imipenem direnci $\% 48,2$ olarak bulunmuştur.

\section{SONUÇ}

Sonuç olarak, son yıllarda enfeksiyon etkeni olan mikroorganizmaların antibiyotiklere artan oranda direnç geliştirdiği göz önüne alındığında, belli zaman aralıklarında bu mikroorganizmaların dağılımlarının ve antibiyotik duyarlılıklarının oranlarının belirlenmesi gerekmektedir. Böylece akılcı antibiyotik kullanımı ile hem artan direncin önüne geçilebilecek hem de toplam tedavi maliyetinin düşürülmesine katkı sağlanabilecektir.

Yazarların Katkıları: Fikir/Kavram: Y.T.Ç.; Tasarım: E.G.T.; Veri Toplama ve/veya İşleme: E.G.T.; Analiz ve/veya Yorum: K.B.; Literatür Taraması: K.B.; Makale Yazımı: Y.T.Ç., K.B.; Eleştirel İnceleme: A.B.

\section{KAYNAKLAR}

1. Gür D. Bakterilerde antibiyotiklere karşı direnç. Topçu AW, Söyletir G, Doğanay M, editörler. İnfeksiyon Hastalıkları. İstanbul: Nobel Tip Kitapevi; 1996. s. 183-90.

2. Yurtsever SG, Kurultay N, Çeken N, Yurtsever Ş, Afşar İ, Şener AG, et al. Yara yeri örneklerinden izole edilen mikroorganizmalar ve antibiyotik duyarlılıklarının değerlendirilmesi. ANKEM Derg.2009; 23(1): 34-8.

3. Karakeçili F, Kalkan A. Yara yönetiminde enfeksiyona yaklaşım. Türkiye Klinikleri J EndocrinSpecial Topics. 2015; 8(3): 44-9.

4. Dai T, Huang YY, Sharma SK, Hashmi JT, Kurup DB, Hamblin MR. Topical antimicrobials for burn wound infections. Recent Pat Anti Infect Drug Discov. 2010; 5(2): 124-51.

5. Ayton M. Woundcare: Wounds that won't heal. Nurs Times. 1985; 81(46): 16-9.

6. Coşkun Ö, Uzun G, Dal D, Yıldız Ş, Sönmez YA, Yurttaş Y, ve ark. Kronik yarada tedavi yaklaşımları. Gülhane Tip Dergisi. 2016; 58: 207-28. doi: 10.5455/gulhane. 180868 .

7. Zafar A, Anwar N, Ejaz H. Bacteriology of infected wounds - a studyconducted at children hospital Lahore. Biomedica. 2007; 23: 1-4.

8. Sümer Z, Bakıcı Z, Türkay C, Gökçe G, Gökgöz Ş. Yatırılarak izlenen hastaların yara yeri ve idrar örneklerinde izole edilen mikroorganizmaların değerlendirilmesi. Türk Mikrobiyol Cem Derg. 2001; 31(1-2): 48-52.

9. European Committee on Antimicrobial Susceptibility Testing (EUCAST). Available from: http://www.eucast.org.

10. Gündem NS, Çıkman A. Yara kültürlerinden izole edilen mikroorganizmalar ve antibiyotik duyarl111klar1. ANKEM Derg. 2012; 26(4): 165-70.

11. Sesli Çetin E, Kaya S, Taş T, Cicioğlu Arıdoğan B, Demirci M. Cerrahi alan infeksiyonlarında mikroorganizma profili ve antibiyotik duyarlılık durumu. ANKEM Derg. 2006; 20(2): 89-93.

12. Hoşaf E, Çalıca A, Çetin BD, Seber E. Yara, abse ve akıntı örneklerinden elde edilen Pseudomonas aeruginosa suşlarının antibiyotiklere duyarlılıkları. Türk Mikrobiyoloji Cem Derg. 2001; 31(1-2): 18-21. 
13. Byrne DJ, Napier A, Cuschieri A. Rationalizing whole body disinfection. J Hosp Infect. 1990; 15(2): 183-7.

14. Altan G, Mumcuoğlu İ, Hazırolan G, Dülger D, Aksu N. Yara örneklerinden izole edilen mikroorganizmalar ve antimikrobiyallere duyarlılıkları. Turk Hij Den Biyol Derg. 2017; 74(4): 279-86.

15. Cirit OS, Müderris T, Mizraklı AU, Vurupalmaz Y, Barış A. Yara kültürlerinden izole edilen aerop bakteriler ve antibiyotik duyarlılıkları. Türk Mikrobiyol Cem Derg. 2014; 44(4): 149-57.

16. Aşık G, Özoğuz P, Tünay H, Bulut A, Kaçar SD, Bal A. Yara kültürlerinden izole edilen etkenler ve antibiyotik direnç profilleri. Cerrahi Sanatlar Derg. 2014; 7(1): 18-22.

17. Doğan SŞ, Paköz NIE, Aral M. Laboratuvarımıza gönderilen yara yeri örneklerinden izole edilen mikroorganizmalar ve antibiyotiklere direnç durumları. Türk Mikrobiyol Cem Derg. 2010; 40(4): 243-9.

18. Vilar-Compte D, Mohar A, Sandoval S, Rosa M, Gordillo P, Volkow P. Surgical site infections at the national cancer institute in Mexico. A case control study. Am J Infect Control. 2000; 28(1): 14-20.

19. Mama M, Abdissa A, Sewunet T. Antimicrobial susceptibility pattern of bacterial isolates from wound infection and their sensitivity to alternative topical agents at Jimma University Specialized Hospital, South-West Ethiopia. Ann Clin Microbiol Antimicrob.2014; 13: 14-7. doi: 10.1186/1476-071113-14.

20. Öksüz L, Gürler N. Klinik örneklerden izole edilen metisiline dirençli stafilokok suşlarının son yıllarda kullanıma giren antibiyotiklere in-vitro duyarlılık sonuçları. ANKEM Derg. 2009; 23(2): 71-7.

21. Efe S, Sinirtas M, Ozakin C. In vitro susceptibility to linezolid in methicillin-resistant Staphylococcus aureus and vancomycin-resistant Enterococcus strains. Mikrobiyol Bul. 2009; 43(4): 639-43.

22. Adaleti R, Nakipoglu Y, Ceran N, Tasdemir C, Kaya F, Tasdemir S. Prevalence of phenotypic resistance of Staphylococcus aureus isolates to macrolide, lincosamide, streptogramin B, ketolid and linezolid antibiotics in Turkey. Braz J Infect Dis. 2010; 14(1): $11-4$.

23. Tsiodras S, Gold HS, Sakoulas G, Eliopoulos GM, Wennersten C, Venkataraman L, et al. Linezolid resistance in a clinical isolate of Staphylococcus aureus. Lancet. 2001; 358(9277): 207-8.

24. Özcan N, Durmaz ÇB, Oktar M. Yara örneklerinden izole edilen stafilokok suşlarının çeşitli antibiyotiklere direnç oranlarının araştırılması. Eraksoy H, editör. XI. Türk Klinik Mikrobiyoloji ve İnfeksiyon Hastalıkları Kongresi; 2003; İstanbul. İstanbul: Turgut Yayıncılık; 2003. s. 350.
25. Polat Y, Karabulut A, Balcı YI, Çilengir M, Övet G, Cebelli S. Yanık olgularında kültür ve antibiyogram sonuçlarının incelenmesi. Pamukkale Tıp Derg.2010; 3(3): 131-5.

26. Kiremitçi A, Durmaz G, Akgün Y, Kiraz N, Aybey A, Yelken B. Anestezi yoğun bakım ünitesinde çeşitli klinik örneklerden üretilen mikro-organizmalar ve antibiyotik direnç profilleri: 2003 yılı verileri. İnfeksiyon Derg. 2006; 20(1): 37-40. 